日平滑筋誌（Jap, J. Smooch Muscle Res. ) 15:21-27, 1979.

\title{
ヒト胆囊条片運動について
}

一䏣囊条片運動に関する研究 (第 2 報 $)$ 一

\author{
弘前大学医学部 第二外科学教室 \\ 杉山譲, 原田正夫, 羽田隆吉 \\ 小沢 正則, 小舘昭示, 小野 慶一
}

\section{IN-VITRO MOTILITY STUDIES ON THE STRIPS OF THE HUMAN GALLBLADDER}

\author{
Yuzuru Sugiyama, Masao Harada, Ryukichi Hada, Masanori Ozawa, \\ Shoji Kodate and Keiichi Ono \\ Department of Surgery, Hirosaki University School of Medicine, Hirosaki. \\ (Director: Prof. K. Oh-Uti)
}

Studies in-vitro motility of the human gallbladder was investigated in the longitudinally cut strips obtained from 24 patients.

Strips of the wall of the organ, containing mucosa, muscle and serosa, $5 \mathrm{~mm}$ in width and $15 \mathrm{~mm}$ in length, were cut from the fundus, body and neck.

These specimens were suspended in Tyrode solution at $36^{\circ} \mathrm{C}$ equilibrated with the $100 \% \mathrm{O}_{2}$.

Recordings were made on a pen chart recorder which were transduced using a isometric system by the changes of contractions.

The results obtained were as follows.

1. The strips from three parts of the gallbladder showed rhythmic and tonic spontaneous contractions.

2. The tonic contractions from fundus were strongest in those three.

3. The rhythmic contractions of neck exhibited greater amplitude than those of fundus and body.

\section{I. は じめに}

さきに第 1 報で原田（1979）が述べたごとく， イヌ胆囊を用い頸部，体部，底部より同じ大きさ の条片を作製, 等尺性収縮による運動を持続的に 記録観察した。その結果安静無作為時の条片運動 は緊張性収縮と律動性収縮より構成されていた。 緊張性収縮は胆囊各部で差異はみとめられなかっ たが, 律動性収縮では頸部, 体部, 底部の波形に 相違がみとめられた。そこでこの実験と並行しな がら究極的な目的の一つであるヒト胆囊条片はい
かなる運動を呈するかを追求した。

しかしイヌ胆囊と異なり，ヒト胆囊は病的なも のが対象となる場合が多く, その研究には困難が 予想された。またこれら条片運動と胆囊壁の炎症 の程度や術前胆囊造影時における胆囊収縮能など といかなる相関々係にあるのか, 興味深い問題が 多い。今回はこれらの問題はさておき, 得られた 結果より胆囊各部, そなわち頸部, 体部, 底部の 条片運動の差異に的をしぼり述べてみたい。 


\section{II. 実 験 方 法}

\section{A. 実 験 材 料}

実験対象には胆囊結石症 18 例, 無石胆囊炎 3 例, 他疾患 3 例（胆囊ポリープ 1 例, 正常胆囊 2 例で胃癌手術時合併剔除をらけたもの）の計 24 例で，いずれも胆囊剔除をらけたものであった。 性別は男 7 例, 女 17 例, 年令は 30〜 71 歳, 平均 55 歳であった。手術はすべて全麻下に行なわれ た、胆囊剔除はまず胆囊管を結禁して胆囊内胆汁 の総胆管内への流出を防止した。ついで胆囊底部 より剝離をすすめ, 胆囊壁を錳子などで把持挫隇 しないよらに留意した，胆囊壁の血流をなるべく 温存するため胆囊動脈は最後に結禁するようにし た。

胆囊剔除が終了したところで胆囊壁に条片作製 のために 4-0 絹糸によるマークをつけた.ついで 胆囊を肝床部で縦に開き， $\mathrm{O}_{2}$ を流しながら $36^{\circ} \mathrm{C}$
に加温した Tyrode 液を満した魔法ビンに入れ実 験室に運んでセットした．従って胆囊剔除よりセ ットするまでに要した時間は他病院の症例もあり 最短 15 分〜最長 2 時間であった.

\section{B. 実験裝置および方法}

セットアップに先立ら同一胆囊における肝付着 反対側面で, 縦軸方向同一直線上で胆囊頸部, 体 部, 底部より縦に長い生体長 $15 \times 5 \mathrm{~mm}$ の条片を 採取した。条片の長さが生体長に復帰するまで伸 展するのに要した力は, イヌ胆囊と同様およそ $1.2 \mathrm{~g}$ 前後であった。実験装置, 潅流方法および 測定方法は第 1 報（原田，1979）と全く同様であ る。なお観察はすべて安静無作為時で行ない薬剤 の投与は一切行なわなかった。

\section{III. 実 験 結 果}

\section{A. 条片運動の安定期}

24症例中得られたデータが分析に適切と判断さ れたものは 23 症例であった．以下この 23 症例の 分析結果について述べる。すなわち胆囊各部の条 片運動はイヌ胆囊条片運動と同様長く緩慢に続く 緊張性収縮と上下に動摇のはげしい律動性収縮よ りなり, 両者とも時間の経過と共に変化した。

\section{1. 緊張性収縮}

まず緊張性収縮は $1.2 \mathrm{~g}$ 前後の負荷をかけると

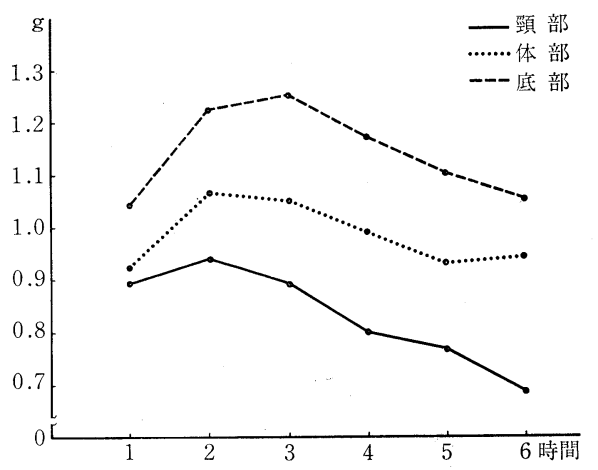

張力を $\mathrm{g}$ 単位で示す

図 1 . 緊張性収縮（張力）
条片の張力（緊張性収縮力）はすみやかに最大值 に達し, その後下降し続けおよそ30分で最小值 に達した。 しかしその後は漸増し $2 \sim 3$ 時間で最 大值に達した後, 時間の経過とともに泍減した。

この緊張性収縮力の平均值を部位別の時間推移 で表わしたものが閔 1 である。これによると緊張 性収縮はイヌ胆囊条片と異なり明らかな部位別差 がでた。すなわち底部で最も強く,ついで体部, 頸部の順であった。 またそのピークはそれぞれ底 部では 3 時間後, 体部では 2 時間後, 頸部では 2 時間後であり最大収縮力は $1.25 \mathrm{~g}, 1.07 \mathrm{~g}, 0.94$ g であった。この緊張性収縮力は頸部と底部の間 で統計学的に有意差 (危険率 0.001 ) がみとめられ た。しかし頸部と体部, 体部と底部の間では有意 差はみとめられなかった。

\section{2. 律動性収縮}

次に律動性収縮波の頻度を測定したところばら つきが多いものの, その平均值は胆囊各部之も時 間の経過とともにほぼ同様の減少傾向を示した。 しかし 1〜3時間の間がほぼ安定した時期（1分 間 3 回前後）と考元られた（図2）。な抗この際， 振幅の大ささに関係なく明らかに上にらの山を形 成するものを 1 個の波とかぞえ 10 分間にわたり 


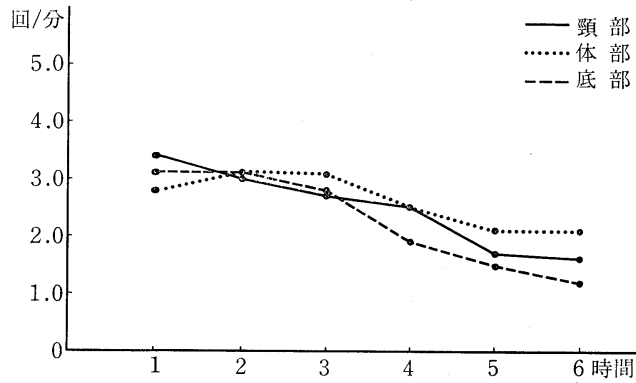

図 2. すべての波の頻度

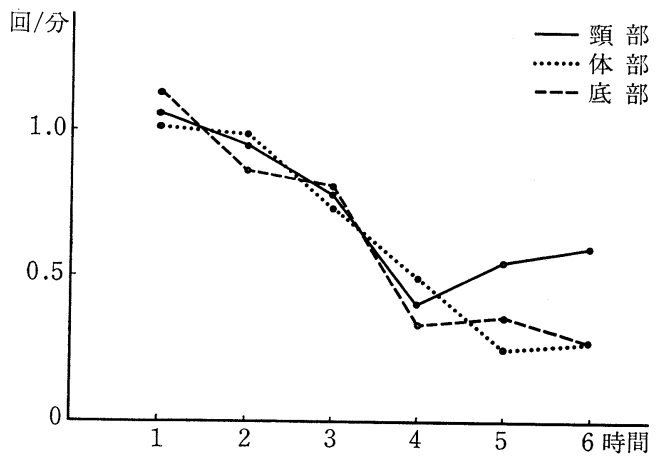

図 3, 主たる波の頻度

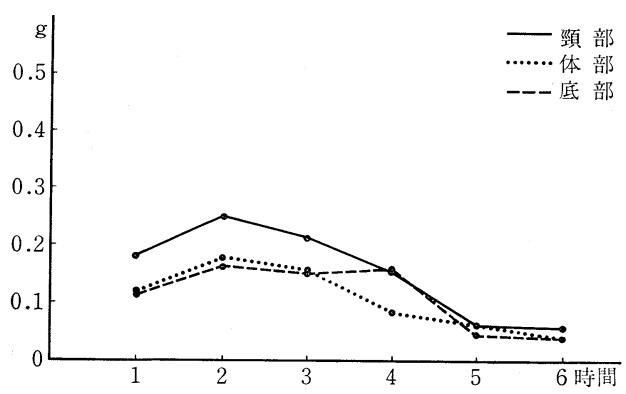

張力を $\mathrm{g}$ 単位で示す

図 4. 律動性収縮（振幅）

カウントし,これを 1 分間あたりの数に換算した。 一方振幅 $0.1 \mathrm{~g}$ 以上の大さい波を第 1 報になら って主たる波としてその時間推移をみたのが図 3 である。これによると胆囊各部とも時間の経過と ともに減少していくのが分る。

さて律動性収縮の振幅を時間の経過と共にみた のが図 4 である.その振幅は頸部で最も大きく, ついで体部と底部が時間の経過とともに溸減しな

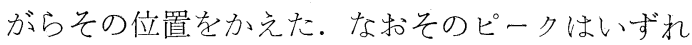
も 2 時間目であり，それぞれ $0.25 \mathrm{~g}, 0.18 \mathrm{~g}$ ，

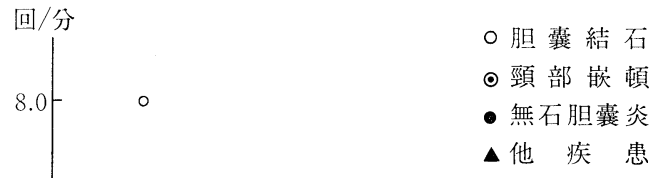

$0.16 \mathrm{~g}$ であった.

以上の結果を小括すると条片運動の最も安定し た時期は $2 \sim 3$ 時間目と考光られ, 頸部, 体部, 底部の各条片運動の比較は 2 時間後とすることに した。

\section{B. 胆囊各部条片運動の比較}

前述したごとく条片運動には緊張性収縮と律動 性収縮とがみられる。緊張性収縮はいずれの時間 でも底部が明らかに優勢であり,ついで体部, 頸 部の順であった。また底部と頸部との間には統計 学的有意差をみとめている。一方律動性収縮では 波の頻度は時間とともに漸減し, 振幅ははじめの $2 \sim 3$ 時間は漸增し，その後は時間の経過ととも に漸減する傾向がうかがえた。そこでさきに述へ た条片運動の安定期と考光られる 2 時間目の律動 性収縮の波形を中心に検討してみた。

\section{1. すべての波の頻度（図 5)}

ばらつきが多いもののまず頸部では，最多 7.9 回/分, 最少 0.8 回/分, 平均 3.0 回/分であった. 次に体部では最多 5.0 回/分, 最少 0.7 回/分, 平 均 3.1 回/分, さらに底部では最多 5.3 回/分, 最 


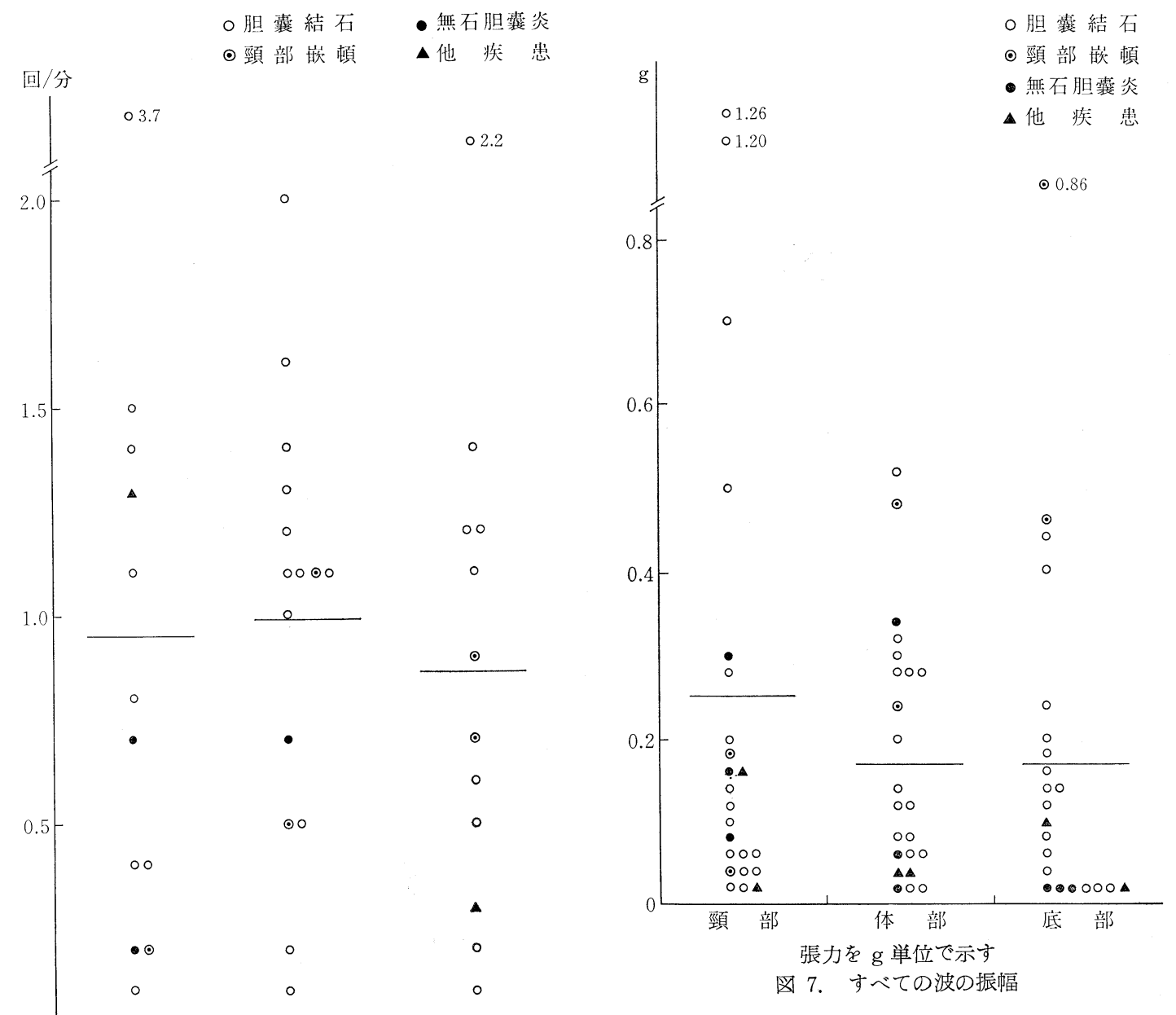

平均 0.99 回/分, 底部では最多 2.2 回/分, 最少

図 6. 主たる波の頻度

少 0.3 回/分, 平均 3.1 回/分であった. 胆囊各 部におけるすべての波の頻度に統計学上有意差は みとめられなかった。 またとの頻度を一応疾患別 にプロットしてみたが症例数の関係もあり, 一定 の傾向は出ていない。

\section{2. 主たる波の頻度（図 6 ）}

各部にお壮る波のらち主たる波についてもす心゙ ての波と同様の測定を行なった。な拉たる波の 出現しない症例は頸部で 11 例, 体部で 8 例, 底 部で 11 例あり, これらはこの項目の検索より除 外した。

すべての波と同じくばらつきは多いが，まず頸 部では最多 3.3 回/分, 最少 0.1 回/分, 平均 0.95 回/分, 体部では最多 2.0 回/分, 最少 0.1 回/分, 0.1 回/分, 平均 0.86 回/分であった。すべての 波同様各部にさしたる差異はみとめられなかっ た。

\section{3. すべての波の振幅（図 7 )}

まず頸部では最大 $1.26 \mathrm{~g}$, 最小 $0.02 \mathrm{~g}$, 平均 $0.25 \mathrm{~g}$, 体部では最大 $0.52 \mathrm{~g}$, 最小 $0.02 \mathrm{~g}$, 平均 $0.17 \mathrm{~g}$, 底部では最大 $0.86 \mathrm{~g}$, 最小 $0.02 \mathrm{~g}$, 平均 $0.16 \mathrm{~g}$ で, ばらつさはあるものの頸部にやや大さ い傾向がみとめられた。また図をみて気付くのは 胆囊結石の頸部嵌頓例が 2 例とも体部, 底部の振 幅が頸部のそれより明らかに大きいことである。 この点に関しては症例を重㸚さらに検討を要する 問題である.

\section{4. 振幅の比 (図 8 )}

前述したごとく胆囊各部の振幅は頸部にやや大 


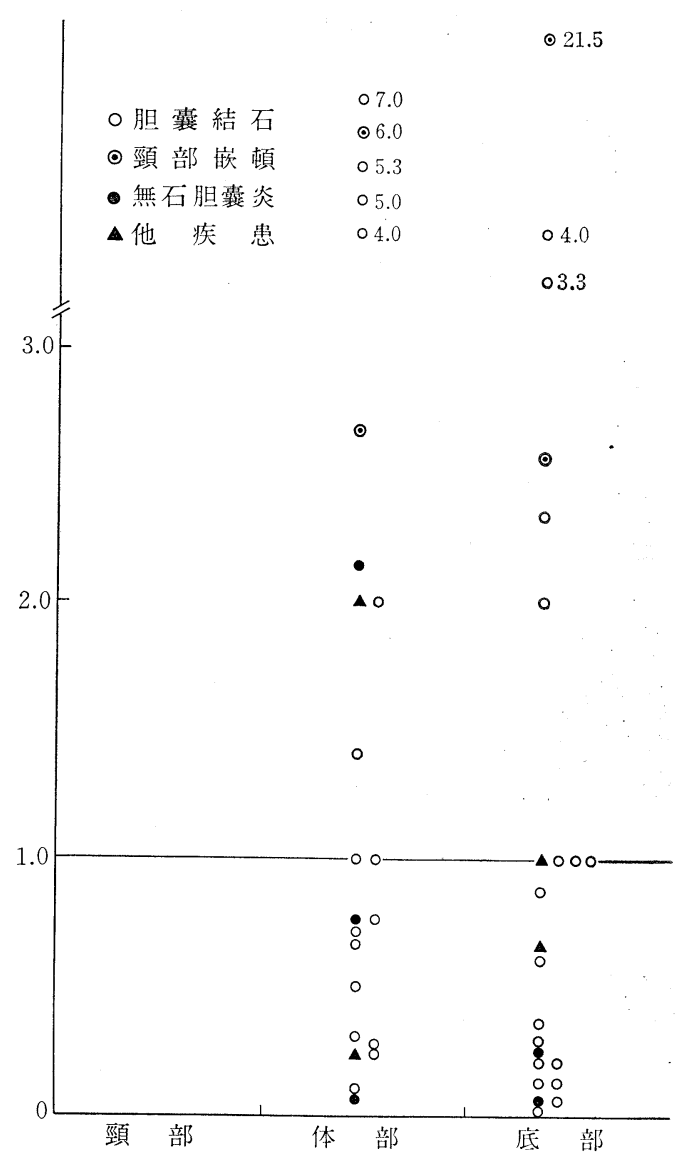

図 8. 振幅の比
きい傾向がみられる他はっきりした差異はみいだ せなかった。そこで各症例毎に体部掞よび底部の 振幅を頸部の振幅に対する比で表わしてみた。そ れによると頸部より大さい振幅を呈するものは体 部では 10 例, 底部では 6 例, 同じ振幅のものは それぞれ 2 例, 4 例, 小さい振幅のものはそれぞ れ 11 例，13 例で，体部に底部より振幅の大きい ものがやや多いといら他はいずれもはっきりした 差異はみいだせなかった。しかしここでも前項の すべての波の振幅と同様胆囊結石の頸部嵌頓例が 著明に大きい比を示した。

\section{5. 各部の典型例}

緊張性収縮力（張力）は底部, 体部, 頸部の順 であった。しかし律動性収縮となるとその波の頻 度にはほとんど部位別差はなく，わずかに振幅は 頸部が大きく，ついで体部，底部の順であった。 したがって波型の典型例は頸部は振幅の大きい波 が，底部では緊張性収縮の強い波，体部ではその 中間型とでもいえよう。いずれにしてもイス胆囊 にお壮るよらな部位別差のはっきりした波型は 23 症例の分析では出ていない.

いまここで律動性収縮が頸部で著明な 1 例（図 9 ），底部や体部で著明な 1 例（図 10）を示す。
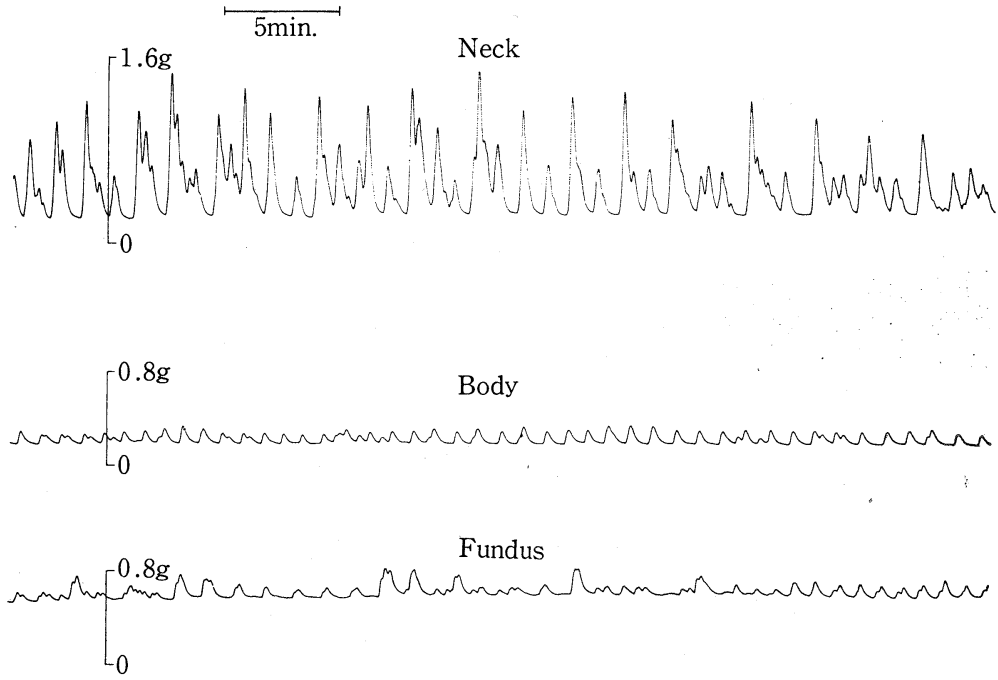

図 9. 律動性収縮が頸部で著明な例 


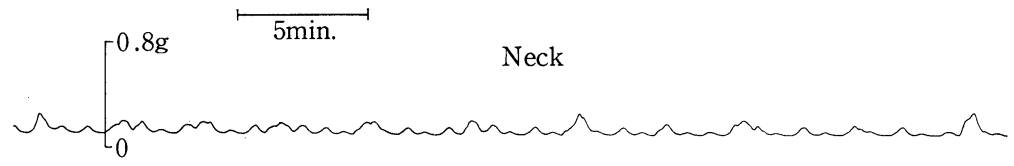

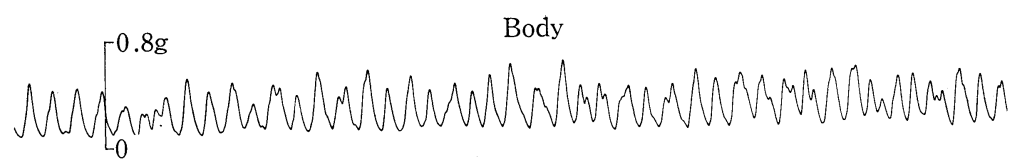

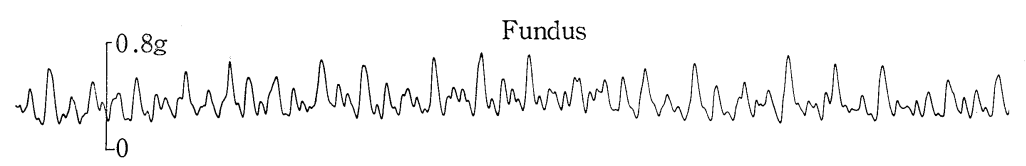

図 10. 律動性収縮が体部, 底部で著明な例

\section{IV. 総 括 と考案}

これまで胆囊運動を知る一つの観察手段として 胆囊条片を用いた研究は種々なされてきている。 すなわち田北，松永（1951）は犬および猫胆囊よ り幅約 1 乃至 $0.5 \mathrm{~cm}$, 長さ約 $3 \mathrm{~cm}$ の条片を, 山 元 (1952) はイ又胆囊より幅 $5 \mathrm{~mm}$, 長さ $2 \mathrm{~cm}$ の 条片を，また Toouli, Watts (1971，1975) はイ 又胆囊より $1 \times 3 \mathrm{~cm}, 1 \times 4 \mathrm{~cm}$ の条片を採取しそ れぞれ条片運動について述べている。一方 Mack, Todd (1968) はわれわれと同様ヒ卜胆囊において 同一標本より輪状方向と縦軸方向からそれぞれ $20 \times 2 \mathrm{~mm}$ の条片を採取, 条片運動を記録観察し ている.

しかしながらこれらの胆囊条片運動に関する研 究では, 条片の大ささについての記載はみられる が，その採取部位についてはいずれも明確にされ ていない。

ところで教室におけるこれまでの胆囊運動の映 像工学的観察 (工藤, 1976; 杉山, 1972; 岩谷, 1977）や第 1 報（原田，1979）の結果より，胆囊 運動には部位による差異のあることが十分考えら れる。

そこでわれわれはヒト胆囊条片運動の部位別差 異について検討すべく, 第1報（原田，1979）で 述べた方法にしたがって胆囊各部より条片を採取 した。すなわち剔除胆囊肝付着反対側面で, 縦軸 方向同一直線上で胆囊頸部, 体部, 底部より縦に
長い $15 \times 5 \mathrm{~mm}$ の条片を採取, 等尺性収縮運動に ついて検討した.

その結果ヒ卜胆囊各部の条片運動はイヌ胆囊の それと同様長く緩慢に続く緊張性収縮と上下に動 摇のはげしい律動性収縮よりなり，両者共時間の 経過とともに変化した。緊張性収縮は $2 \sim 3$ 時間 で最大值に達した後, 時間の経過とともに漸減し た。また緊張性収縮力（張力）はイ又胆囊と異な り明らかな部位別差異がみとめられた。すなわら 底部で最も強く, ついで体部, 頸部の順であっ た。な敃底部と頸部の間で統計学的有意差をみと めている。

律動性収縮の波の頻度はイ又胆囊条片運動と異 なりばらつきが多いもののその平均值ではすべて の波，主たる波とも時間の経過とともに注涪同様 の漸減傾向を示した。しかし振幅ははじめの 2 3 時間は漸増しその後は時間の経過とともに漸减 するものの, 頸部でやや大きい傾向がみとめられ た。そこでこれら条片運動の安定期である 2 時間 目の各部の律動性収縮波について比較検討した。

その結果すべての波の頻度は胆囊各部で平均 3. 0 3.1 回/分で部位別差はみとめられなかっ た。また主たる波の頻度も0.86 0.99回/分と胆 囊各部における差異はみとめられなかった。また すべての波の振幅は頸部で平均 $0.25 \mathrm{~g}$, 体部, 底 部ではそれぞれ $0.17 \mathrm{~g}, 0.16 \mathrm{~g}$ と頸部にやや大 
きい傾向がみとめられた。これら緊張性収縮と律 動性収縮が胆囊内胆汁の流入, 排出に際していか なる働きをしているのであろらか. 条片運動の観 察結果よりその詳細をらかがい知ることはむずか しい.

ところで教室工藤（1976）によればイ又胆囊運 動低速 X線映画撮影に拈いて以下の如く述べてい る.すなわら安静無作為時連続的観察において, 緩慢な緊張性収縮のほかに頸部ないし体部に蠕動 様運動に類似した所見をみとめている。また杉山 (1972) はヒト胆囊造影の連続的観察で頸部にかす かな蠕動様変化を, 岩谷（1977）は stop motion 方式による胆囊映像輪郭の重社合わせにより胆囊 が頸部より底部において著明な一様な持続的能動

\section{V. む}

胆囊運動の部位別差異について検討すべく各種 疾患にて胆囊剔除した24症例を用い, 胆囊頸部, 体部, 底部より生体長 $1.5 \times 5 \mathrm{~mm}$ の条片を採取, 等尺性収縮運動について持続的に記録観察した。 得られた結果は以下のごとくであった.

1）七ト胆囊各部の条片運動は長く緩慢に続く 緊張性収縮と上下に動摇のはげしい律動性収縮よ りなり, 両者共時間の経過とともに変化した。
的収縮により縮小するのをみとめている，以上の 映像工学的観察結果をまとめてみると, 観察対象 や観察方法が異なるものの, 胆囊頸部ないし体部 には蠕動梯運動に類似した所見あるいは変化を, 底部には著明な一様な持続的能動的収縮をみとめ たといら。

ところで条片運動の観察結果をみると底部には 長く緩慢に続く緊張性収縮が著明で, 頸部には上 下に動摇のはげしい律動性収縮の振幅が大きい傾 向にあった。

これら二通りの研究は観察方法が全く異なるも のの, 胆囊運動の部位別差異についてはある程度 の一致点が見いだせるようである。

\section{す び}

2）緊張性収縮は $2 \sim 3$ 時間で最大值に達した 後, 時間の経過とともに漸減した。 またその収縮 力（張力）は底部で最も強く, ついで体部, 頸部 の順であった。

3）律動性収縮の波の頻度はばらさきが多いも のの, すべての波, 主たる波とも時間の経過とと もに注ぼ同様の溸減傾向を示した。しかしながら 振幅は頸部でやや大きい傾向がみとめられた。

献

原田正夫 (1979)。 イヌ胆囊条片運動について。胆囊条片運動に関する研究. 第 1 報 日平滑筋誌 15: 1-19. 岩谷昭雄 (1977)。 ヒト胆囊運動のグラフペンシステムによる映像計測について。 日消外会誌 10：28-45. 工藤興寿 (1970)。イヌにおける胆霔運動の映像工学的観察。 日平滑筋誌 12: 25-36.

Mack, A.J. \& Todd, J.K. (1968). A study of human gall bladder muscle in vitro. Gut 9: 546-549. 杉山 譲 (1972)。 ヒトに打引る胆囊運動の映像工学的観察. 日平滑筋誌 8: 55-70.

田北周平，松永英剛（1951）。胆囊は如何様に動くが. 最新医学. 6: 1053-1057.

Toouli, J. \& Watts, J.M. (1971). In-vitro motility studies on the canine and human extrahepatic biliary tract. Aust. NZ. J. Surg. 40: 380-387.

Toouli, J. \& Watts, J.M. (1975). Actions of cholecystokinin/pancreozymin, secretin and gastrin on extra-hepatic biliary tract motility in vitro. Ann. Surg. 175: 439-447.

山元七次 (1952). 盰外胆道の楽理学的研究. 医学研究. 22: 564-578.

(1979 年 4 月 4 日受付) 